R E S E A R C H A R T I C L E

\title{
Effect of Puguntano Extract (Curanga Fel-Terrae Merr.) on hs-CRP Level in Newly Diagnosed Type 2 Diabetes Mellitus Patient
}

\author{
Hartono Apriliasta Purba*, Santi Syafril, Dharma Lindarto \\ Endocrine and Metabolic Division, Department of Internal Medicine Faculty of Medicine, University of Sumatera Utara/ Haji Adam Malik \\ General Hospital, Jl. Bunga Lau No.17, Kemenangan Tani, Medan, Indonesia, 20136 \\ ${ }^{*}$ Corresponding author. E-mail: poerba_man@yahoo.com
}

Received date: Aug 28, 2017; Revised: Oct 25, 2017; Accepted: Nov 1, 2017

\section{Abstract}

B ACKGROUND: Inflammation is one of the factors that associated with insulin resistance which causes type 2 diabetes mellitus (T2DM). Inflammation can be measured by using high sensitivity C-reactive protein (hsCRP), a quantitative measurement of CRP concentration. Puguntano is a plant that traditionally used for antidiabetic treatment found in North Sumatera. The objective of this study is to know the effect of Puguntano extract on hs-CRP level in newly diagnosed T2DM patient.

METHODS: The study was a randomized controlled clinical trial on 24 newly diagnosed T2DM patients. Subjects were divided into 2 groups. The first group was given Puguntano extract with starting doses at $100 \mathrm{mg}$ daily, then the dose was increased in titration up to a maximum dose of $2 \times 100 \mathrm{mg}$ daily depending on blood sugar level monitoring. Meanwhile, the other group (which serves as

\section{Introduction}

Diabetes mellitus (DM) is a group of chronic metabolic diseases and a severe problem in the community. Although there are many pathogenic factors involved in type $2 \mathrm{DM}$ (T2DM), it is quite difficult to estimate which type of mechanism is involved in different tissues. Nevertheless, it is still noteworthy that all these cellular stress mechanisms are considered to overlap with each other and provoke inflammation in pancreatic tissues.(1-3)

One of the markers that can be used to measure inflammation is $\mathrm{C}$-reactive protein (CRP). CRP examination a control group) was given metformin with starting doses at $500 \mathrm{mg}$ daily, then the dose was increased in titration up to a maximum dose of $3 \times 500 \mathrm{mg}$ per day depending on blood sugar level monitoring. The hs-CRP and HbAlc are assessed at the baseline and after 12 weeks of treatment.

RESULTS: The hs-CRP level was decreased in Puguntano group by $1.41(-7.54-0.52)(p=0.06)$ and decrease by 0.58 $(-7.86-33.41)(p=0.695)$ in metformin group. There was no difference in hs-CRP level between the two groups $(p=0.630)$.

CONCLUSION: Puguntano extract showed the effect of lowering $\mathrm{HbA1C}$ and hs-CRP level in T2DM patients, although it was not statistically significant.

KEYWORDS: type 2 diabetes mellitus, hs-CRP, puguntano

Indones Biomed J. 2018; 10(1): 79-83 can detect acute inflammation and severe tissue damage. High sensitivity CRP (hs-CRP) is a quantitative measure of CRP concentrations which can measure levels up to $<0.2$ $\mathrm{mg} / \mathrm{L} .(4)$

Pick Up, et al., suggested an increased attention to the involvement of chronic low-grade inflammation and activation of the innate immune system in the pathogenesis of T2DM. CRP is an inflammatory marker that is produced and released by the liver under the influence of cytokines such as tumor necrosis factor (TNF), interleukin (IL)-1 and IL-6.(5) Some prospective studies have suggested that increased CRP level is associated with an increased risk of T2DM.(6) 
Puguntano (Curanga fel-terrae Merr), a medicinal plant from Scrophulariaceae family, grows in Asia, especially in China, India, Indonesia, Philippines, Malaysia and Myanmar. In Indonesia, people in Tiga Lingga Village, Dairi district, North Sumatera, has traditionally used Puguntano leaves as an antidiabetic treatment. This plant is also believed to be effective in relieving pain, increasing endurance, or even used for anti-aging. This plant has now been started to be cultivated by the local community as a medicinal plant.

One study shows that ethanol extract of Puguntano leaf has a potential effect as an anti-inflammatory.(7) On the other hand, another study has conducted a clinical trial and reported that Puguntano leaf, Simplicia powder, has an effect in lowering blood sugar levels in patients with diabetes mellitus, if given orally with the dose of 2 gram steeped in water, 3 times a day, for 14 days.(8) Based on the background above, the aim of this study is to investigates the effect of Puguntano extract in decreasing the hs-CRP level in T2DM patients.

\section{Methods}

Consecutive random sampling was used to select newly diagnosed T2DM subjects, and the study was double-blind to the assigned treatment. Subjects were provided with the information regarding the study, and those agreeing to participate filled the written informed consent. The study was conducted in the outpatient clinic of Haji Adam Malik General Hospital, Medan, from February to July 2016. The study protocol was approved by the ethics committee of Faculty of Medicine, University of Sumatera Utara (Ethical No.: 83/KOMET/FK USU/2016). The study was conducted in accordance with good clinical practice (GCP) and all applicable required regulation. Inclusion criteria were male and female patients, whose age above 17 years, newly diagnosed T2DM and willing to fill the written consent voluntary prior to the study. T2DM was diagnosed based on American Diabetes Association (ADA) and The Indonesian Society of Endocrinology (Perkumpulan Endokrinologi Indonesia/PERKENI) criteria.(15,16) The exclusion criteria were patient with anemia (for male $\mathrm{Hb}<12 \mathrm{~g} / \mathrm{dL}$ or female $\mathrm{Hb}<11 \mathrm{~g} / \mathrm{dL}$ ), hypertension (systolic blood pressure $\geq 140 \mathrm{mmHg}$ and/or diastolic blood pressure $\geq 90 \mathrm{mmHg}$ ), impaired renal function (creatinin $>2 \mathrm{mg} / \mathrm{dL}$ ) and hepatic function (SGOT/SGPT $>2 \mathrm{x}$ upper normal limit, severe infection and did not complied with research procedure (drop out).
Anamnesis was performed to obtain demographic data (include age and sex), height, weight, waist circumference, history of diabetes mellitus, history of smoking, family history of the disease, history of hypertension and previous laboratory examination. Blood collection was performed after 10-12 hours fasting for laboratory assessment. All eligible subjects then randomly devided into treatment groups (which treated with Puguntano extract) and control groups (treated with metformin) by simple random sampling. All subjects in the treatment group were given Puguntano with starting doses at $100 \mathrm{mg}$ daily. Blood sugar level was monitored using glucose dipsticks weekly. When DM target therapy had been achieved, the dose was maintained, whereas if the target had not been reached then dose was increased in titration up to a maximum dose of $2 \times 100$ mg daily. All subjects in the metformin group were given metformin with starting doses at $500 \mathrm{mg}$ daily. Blood sugar levels also monitored weekly using dipstick. When DM target therapy had been achieved, the dose was maintained, whereas if the target had not been achieved then the dose was increased in titration up to a maximum dose of $3 \times 500 \mathrm{mg}$ per day. Interventions for both groups were conducted for 12 weeks. All subjects were monitored by checking blood sugar weekly at the endocrinology metabolic outpatient clinic Haji Adam Malik Hospital, Medan, and each patient was also given a telephone number that can be contacted, in case any side effects shows up.

For both groups of patients, blood samples were taken in the cubital fossa area for examination of hs-CRP levels at the baseline and after 12 weeks of treatment. The hs-CRP was examined by using immunoturbidimetri method with architect i system tools at Prodia Laboratory in S. Parman, Medan, North Sumatera.

Puguntano extract was made by percolation method using $70 \%$ ethanol solvent. A 300 gram of Simplicia powder was incorporated into a lid and moistened with $50 \%$ ethanol liquid, macerated for 3 hours. The mass was transferred bit by bit into the percolator, and then the liquid of the pellet was poured sufficiently until there was a layer of liquid of the dancer above the Simplicia and left for 24 hours. The liquid was allowed to drip at a rate of $1 \mathrm{~mL}$ per minute, the liquid was repeatedly added so that there is always a layer of liquid on the Simplicia, percolation was stopped until the last polishing out was not colored. Percolate was concentrated by using rotavapor, after the thick extract was obtained, then it was dried in a freeze dryer.

Puguntano leaf extract was at doses of $100 \mathrm{mg}$ and mixed with fillers until the capsule weight of $500 \mathrm{mg}$ used capsule shell number 0. Puguntano leaf extract was 
condensed gradually with filler and drier (amylum manihot $5 \%$, amylum maydis $2.5 \%$ and lactic saccharin) to obtain a compact mass, then made granules by sieving the mass. It was dried in the drying cupboard for 1 hour to obtain dry granules, and was being rejuvenated and mixed with lactic saccharum until it reaches the appropriate weight. Then it was inserted into capsule shell with the aid of capsule filler.

Tabulation was used to show the descriptive characteristics of subjects. Shapiro-wilk analysis was performed to assess the normality of data. Wilcoxon analysis was performed to assess the differences between each group. Mann Whitney analysis was used to assess the differences between intergroup. Data were processed and analyzed by using SPSS 22.0 for windows (SPSS Inc, Chicago, USA), with significance level of $p<0,05$.

\section{Results}

Total 24 subjects of T2DM were recruited and met the eligibility. The subjects randomly assigned into two groups, 12 subjects in each group. Baseline characteristics of the subjects in this study are shown in Table 1. Baseline values of all measured parameters were comparable between Puguntano and metformin group.

Shapiro-wilk analysis was performed to assess the normality of data. Because the data do not normally distributed, comparative analysis for each group was performed wiith wilcoxon analysis. Meanwhile to assess the differences between intergroup, Mann Whitney analysis was performed. Table 2 shows that subjects receiving Puguntano extract have significant differences of fasting blood sugar and HbAlc levels before and after treatment $(p<0.05)$. While hs-CRP levels showed a decrease 1.41 (-7.54-0.52), from $2.79(0.2-9.63)$ before the treatment and $1.28(0.24-$ 3.3) after treatment. However, using the Wilcoxon test, no significant difference was found between before and after treatment $(p=0.06)$.

In the subjects receiving metformin, fasting blood glucose and HbA1c level showed significant differences between before and after metformin $(p<0.05)$. While on hs-CRP, the hsCRP level was decreased 0.58 (-7.86-33.41) from 2.87 (0.6-9.94) before treatment and 2.29 (1.01-36.97) after treatment. Based on Wilcoxon test, no significant difference was found $(p=0.695)$.

\section{Discussion}

The use of traditional medicine continues to grow rapidly in the community. This is supported by various factors and issues that develop at this time in the attitude back to nature. The utilization of traditional medicine in various regions is hereditary heritage based on experience/empirical then developed through scientific proof through pre-clinical test and clinical trials.(9) Puguntano (Curanga fel-terrae (Lour.) Merr.) often called Picria fel-terrae is a plant of the Scrophulariaceae family that grows in Asia, especially

Table 1. Baseline characteristics of subjects.

\begin{tabular}{lccc}
\hline \multicolumn{1}{c}{ Characteristics } & $\begin{array}{c}\text { Puguntano, } \\
\text { Median (IQR) }\end{array}$ & $\begin{array}{c}\text { Metformin, } \\
\text { Median (IQR) }\end{array}$ & $p$ \\
\hline Sex & & & \\
$\quad$ Male & 3 & 8 & \\
$\quad$ Female & 9 & $52.5(40-59)$ & 0.177 \\
Age (years) & $56.5(47-60)$ & & \\
Anthropometry & & $63.25(41-70)$ & 0.594 \\
Body weight (kg) & $62.5(41-75)$ & $156(150-170)$ & 0.787 \\
Body height (cm) & $157.5(148-165)$ & $24.7(17-28.9))$ & 0.811 \\
BMI (kg/m $\left.{ }^{2}\right)$ & $25.4(17-31.2)$ & $94(89-104)$ & 0.664 \\
Waist circumference (cm) & $93.50(88-103)$ & & 0.299 \\
Glucose status & & $169.17(89-349)$ & 0.391 \\
Fasting blood sugar (mg/dL) & $223.17(112-310)$ & $263(82-449)$ & 0.356 \\
2 hours post-prandial blood sugar (mg/dL) & $301(124-410)$ & $8.92(6.10-11.8)$ & 0.371 \\
HbAlc (\%) & $9.65(6.10-17.5)$ & $2.87(0.6-9-94)$ & \\
hs-CRP (mg/dL) & $2.7(0.2-9.63)$ & & \\
\hline
\end{tabular}

IQR: Interquartile range 
Table 2. Comparison of HbA1c parameters, fasting blood sugar, 2 hours post-prandial blood sugar, hs-CRP between before and after Puguntano and metformin interventions for 12 weeks.

\begin{tabular}{|c|c|c|c|c|c|c|c|c|c|}
\hline \multirow[b]{2}{*}{ Variable } & \multicolumn{3}{|c|}{ Puguntano } & \multicolumn{5}{|c|}{ Metformin } & \multirow[b]{2}{*}{$p^{\mathrm{c}}$} \\
\hline & $\begin{array}{c}\text { Before, } \\
\text { Median (IQR) }\end{array}$ & $\begin{array}{c}\text { After, } \\
\text { Median (IQR) }\end{array}$ & $\Delta$ & $p^{a}$ & $\begin{array}{c}\text { Before, } \\
\text { Median (IQR) }\end{array}$ & $\begin{array}{c}\text { After, } \\
\text { Median (IQR) }\end{array}$ & $\Delta$ & $p^{b}$ & \\
\hline $\begin{array}{l}\text { Fasting blood sugar } \\
(\mathrm{mg} / \mathrm{dL})\end{array}$ & $223.17(112-310)$ & $165.50(102-196)$ & $57.67(-24-228)$ & $0.012^{*}$ & $169.17(89-349)$ & $127.50(74-187)$ & $41.67(-22-93)$ & $0.010^{*}$ & 0.773 \\
\hline $\begin{array}{l}2 \text { hours post-prandial } \\
\text { blood sugar (mg/dL) }\end{array}$ & 301.25 (124-410) & $276.25(120-441)$ & $25.00(-211-200)$ & 0.480 & $251.83(82-449)$ & $245.00(76-354)$ & $6.83(-214-162)$ & 0.875 & 0.862 \\
\hline HbAlc (\%) & $9.65(6.10-17.5)$ & $8.13(6.20-12.1)$ & $1.53(-1.8-6.1)$ & $0.022^{*}$ & $8.92(6.10-11.8)$ & $7.44(6.10-10.3)$ & $1.48(-1.8-6.1)$ & $0.012 *$ & 0.686 \\
\hline hs-CRP (mg/L) & $2.79(0.2-9.63)$ & $1.28(0.24-3.3)$ & $1.41(-7.54-0.52)$ & 0.060 & $2.87(0.6-9.94)$ & $2.29(1.01-36.97)$ & $0.58(-7.86-33.41)$ & 0.695 & 0.630 \\
\hline
\end{tabular}

$\Delta:$ difference before and after intervention

$p^{\text {a: }} p$ value difference between before and after (Puguntano group), analyzed by Wilcoxon test

$p^{\mathrm{b}}: p$ value difference between before and after (metformin group), analyzed by Wilcoxon test

$p^{c}: p$ value difference between Puguntano and metformin group, analyzed by Mann-Whitney test

*Significant

in China, India, Indonesia, Philippines, Malaysia, and Myanmar. In Indonesia, this plant is spread in Sumatra, Java, Kalimantan and Maluku. Various studies were conducted to determine the chemical compounds and potential usefulness for health from Puguntano.

One study found a decrease in the inflammatory marker (hs-CRP) in T2DM patients in the Puguntano group after 12 weeks of treatment although this decrease was not statistically significant. Another study mentioned that ethanol extract from Puguntano leaf at $10 \mathrm{mg} / \mathrm{kg}$ of body weight which is given orally in male mice, has similar anti-inflammatory effect with $10 \mathrm{mg} / \mathrm{kg}$ of body weight indomethacin against artificial inflammation induced by $1 \%$ $\lambda$-carragenan solution intraplantar.(7) The n-hexane extract was obtained from leaf Picria fel-terrae lour has the ability to decrease blood glucose level by $44.47 \%$ in mice after 10 days treatment, which is compared the administration of n-hexane isolated from Puguntano at dose $200 \mathrm{mg} / \mathrm{kg}$ of body weight and metformin at dose $50 \mathrm{mg} / \mathrm{kg}$ of body weight in mice. They found no significant reduction on day 10 with $135 \mathrm{mg} / \mathrm{dL}( \pm 11.35)$ of $447.17 \mathrm{mg} / \mathrm{dL}( \pm 6.92)$ in the metformin group and $167 \mathrm{mg} / \mathrm{dL}( \pm 4.76)$ from 513 $\mathrm{mg} / \mathrm{dL}( \pm 15.7)$ in the n-hexane group.(10) This research is also in line with previous research on human by Harfina, et al., which showed that Puguntano leaf, Simplicia powders, had an effect in lowering blood sugar levels in patients with diabetes mellitus at dose of 2 gram 3 times a day, for 14 days, if given orally in the form of steeping. $(8,10)$

Metformin is one of oral hypoglycemic drug that has primary effect of reducing the production of liver glucose (gluconeogenesis) as well as improving peripheral glucose uptake. The efficacy, safety, and beneficial effects of cardiovascular and metabolic make metformin the first choice agent in recent years to lower glucose in the treatment of T2DM patients.(11)

Previous study has found that Puguntano plants contain glycosides, flavonoids, tannins and steroids/triterpenoids. (7) This is also accordance to the finding of Puguntano leaf ethanol extract obtained by percolation and socletation methods contained the same phytochemical content of flavonoids, saponins, tannins, glycosides and steroids/ terpenoids. Chemical compounds that responsible for antiinflammatory effects is steroids/triterpenoids. The antiinflammatory effects of steroid/triterpenoids are related to their ability to inhibit the enzymatic action of phospholipase, thus preventing the release of mediators of inflammatory processes, arachidonic acid and its metabolites, such as prostaglandin, leukotrien, thromboxane and prostacyclin, so further inflammation can be avoided.

From this study we can found that Puguntano extract is able to reduce hyperglycemia in T2DM patients. Its effect also was not much different from metformin which has become the first line standard drugs in the treatment of T2DM. In this study, hs-CRP level in both groups were decreased, although the result was not statistically significant. Steroid/triterpenoids in Puguntano extract act as an antiinflammatory, thereby reducing the inflammatory response. The decrease in hs-CRP level occurring in Puguntano group was also thought due to the improved blood sugar control in subjects before and after treatment, and this might be influenced by the content of other chemical compounds in Puguntano beside steroid/triterpenoids.

While in the metformin group, the finding is consistent with the positive effect of metformin on inflammation markers in patients with impaired glucose tolerance. In a previous study conducted by Chakraborty, et al., a 
significant reduction in serum CRP concentrations was also observed after metformin therapy.(17) Serum hsCRP levels of T2DM patients also exhibited an obvious reduction after treatment with active metformin.(18) But the above results are different from some previous studies that did not find any effect of metformin on hs-CRP levels in T2DM patients. A research in Iraq was done in 103 newly diagnosed T2DM patients (53 patients were given metformin and 50 patients were given glibenclamide). Subjects receiving metformin showed increasing hs-CRP levels from $6.59 \pm 3.19$ before the treatment and $6.12 \pm 2.71$ after treatment. Meanwhile subjects receiving glibenclamide showed increasing hs-CRP levels from $4.95 \pm 2.71$ before the treatment and $5.46 \pm 2.76$ after treatment. The results showed no significant hs-CRP results in patients either metformin group or glibenclamid group after therapy for 2 month.(12) Previous research by De Jager J, et al., found that metformin administration did not affect the level of inflammatory markers (CRP) in T2DM patients.(13) Subjects receiving metformin for 16 weeks showed hs-CRP levels 3.26 (2.803.78) before treatment and 3.34 (2.89-3.86) after treatment.

This current study showed that effect of Puguntano extract on inflammation that supposed to precede and predict the pathogenesis of T2DM almost the same as the effect of metformin. But this study has few limitations, which are: 1) a small sample size, hence the possibility of the actual results can not be reflected; 2) the activity and daily dietary intake of the patients can not be standardized, hence it has influenced the measurement results; and 3) the compliance level of the samples were not assessed.

\section{Conclusion}

Puguntano has been observed to decrease hs-CRP levels, where it acts as an indicator of inflammatory process in T2DM patients. Eventhough the result was not statistically significant, from this research it has been showed that there was an effect of Puguntano extract towards hs-CRP level in T2DM patients, where hs-CRP level decreases by giving Puguntano extract.

\section{References}

1. Donath MY, Schumann DM, Faulenbach M, Ellingsgaard H, Perren A, Ehses JA. Islet inflammation in type 2 diabetes: from metabolic stress to therapy. Diabetes Care. 2008; 31(Suppl 2): S161-4.
2. Hotamisligil GS, Erbay E. Nutrient sensing and inflammation in metabolic diseases. Nat Rev Immunol. 2008; 8: 923-34.

3. Ehses JA, Ellingsgaard H, Böni-Schnetzler M, Donath MY. Pancreatic islet inflammation in type 2 diabetes: From $\alpha$ and $\beta$ cell compensation to dysfunction. Arch Physiol Biochem. 2009; 115: 240-7.

4. Handojo I. Imunoasai Terapan pada Beberapa Penyakit Infeksi. Surabaya: Airlangga University Press; 2004.

5. Pickup JC. Inflammation and activated innate immunity in the pathogenesis of type 2 diabetes. Diabetes Care. 2004; 27: 81323.

6. Laaksonen DE, Niskanen L, Myyssonen K, Punnonen K, Tuomainen $\mathrm{TP}$, Valkonen VP, et al. C-reactive protein and the development of the metabolic syndrome and diabetes in middle-aged men. Diabetologia. 2004; 47: 1403-10.

7. Juwita NA. Karakterisasi Simplisia dan Uji Efek Antiinflamasi Ekstrak Etanol Daun Puguntanoh (Curanga fel-terrae Merr.) terhadap Mencit Jantan. Medan: Fakultas Farmasi Universitas Sumatera Utara; 2009.

8. Harfina F, Bahri S, Saragih A. Pengaruh Serbuk Daun Puguntano (Curanga fel terrae Merr.) Pada Pasien Diabetes Melitus. J Pharm Pharmacol. 2012; 1: 112-8.

9. Depkes RI. Inventaris Tanaman Obat Indonesia (I). Cetakan Pertama. Jakarta: Departemen Kesehatan RI 2000. Halaman 21-22.

10. Sitorus $P$, Harahap U, Pandapotan M, Barus T. Isolation of $\beta$-sitosterol from n-hexane extract of Picria fel-terrae Lour. Leave and study of its antidiabetic effect in alloxan induced diabetic Mice. Int $\mathrm{J}$ PharmTech Res. 2014; 6: 137-41.

11. Akash MS, Rehman K, Chen S. Role of inflammatory mechanisms in pathogenesis of type 2 diabetes mellitus. J Cell Biochem. 2013; 114: 525-31.

12. Abdulkadir AAA, Thanoon IAJ. Comparative effects of glibenclamide and metformin on C-reactive protein and oxidant antioxidant status in patients with type II diabetes Mellitus. Sultan Qaboos Univ Med J. 2012; 12: 55-61.

13. De Jager J, Kooy A, Lehert P, Bets D, Wulffelé MG, Teerlink T, et al. Effects of short-term treatment with metformin on markers of endothelial function and inflammatory activity in type 2 diabetes mellitus: a randomized, placebo-controlled trial. J Intern Med., 2005; 257: 100-9.

14. Harahap U, Patilaya P, Mariane, Yuliasmi S, Husori Di, Prasetyo $\mathrm{BE}$, et al. Profil fitokimia ekstrak etanol daun puguntano [curanga fel-terrae (merr.) lour.] yang berpotensi sebagai antiasma. Seminar Nasional Sains \& Teknologi V Lembaga Penelitian Universitas Lampung. 2013; (n.v) :422-6.

15. American Diabetes Association. Standards of medical care in diabetes. Diabetes Care. 2015; 38 (Suppl 1): S1-93.

16. Perkeni (The Indonesian Society of Endocrinology). Konsensus Diagnosis Dan Penatalaksanaan Diabetes Mellitus. Jakarta: Balai Penerbit; 2015.

17. Chakraborty A, Chowdhury S, Bhattacharyya M. Effect of metformin on oxidative stress, nitrosative stress and inflammatory biomarkers in type 2 diabetes patients. Diabetes Res Clin Pract. 2011; 93: 56-62.

18. Pradhan AD, Everett BM, Cook NR, Rifai N, Ridker PM. Effects of initiating insulin and metformin on glycemic control and inflammatory biomarkers among patients with type 2 diabetes: The LANCET randomized trial. JAMA. 2009; 302: 1186-94. 